Jurnal Health Sains: p-ISSN: 2723-4339 e-ISSN: 2548-1398

Vol. 2, No. 6, Juni 2021

\title{
PENGARUH RELAKSASI NAFAS DALAM DAN PIJAT WAJAH TERHADAP TEKANAN DARAH DAN STRES PADA IBU HAMIL
}

\section{Fenti Hasnani}

Politeknik Kesehatan Kemenkes Jakarta I, Indonesian

Email: fentihasni112@gmail.com

\begin{tabular}{ll}
\hline ARTIKEL INFO & ABSTRACT \\
\hline Diterima: 5 Juni 2021 & Hypertension is very significant contributing to maternal and \\
Direvisi: 15 Juni 2021 & fetal morbidity and mortality so it is necessary to do \\
Disetujui: 25 Juni 2021 & preliminary screening and follow-up during pregnancy. \\
\hline Keywords: & Hypertension is a disease of the cardiovascular system that \\
deep breath relaxation; facial & has high mortality and morbidity. High blood pressure in \\
massage; changes in blood & hypertensive patients can be overcome by pharmacological \\
pressure; stress level; pregnant & and non-pharmacological therapy. One non- \\
women & pharmacological therapy is facial massage therapy and deep \\
& breathing relaxation. This research is a quatitative study with \\
& the method of Non-equivalent Control Group Design with the \\
& Control Group Post test only design approach or post test \\
& control group. The study was conducted at the Puskesmas \\
& Tanah Baru Depok. The sample amounted to 108 people who \\
& were divided into 54 people in the control group and 54 people \\
& in the intervention group. Data was collected through \\
& questionnaires and blood pressure measurement results. \\
Based on the Mann Whitney test results obtained p- value \\
0.001, it can be concluded that there is a difference in the mean \\
systolic blood pressure in pregnant women who do facial \\
massage and deep breathing relaxation. There was a \\
significant difference in the value of stress levels after facial \\
massage and deep breathing relaxation at the stress level (p- \\
value 0.001). The average stress level in pregnantwomen who \\
did not take facial massage and deep breathing relaxation was \\
76.50 \pm 25.5, while for pregnant women who did facial \\
massage therapy and deep breathing relaxation was $60 \pm 16$.
\end{tabular}

\begin{abstract}
ABSTRAK
Hipertensi sangat signifikan berkontribusi terhadap angka kesakitan dan kematian ibu dan janin sehingga perlu dilakukan skrinning awal dan pemeriksaan lanjutan selama kehamilan. Hipertensi merupakan salah satu penyakit pada sistem kardiovaskuler yang memiliki angka mortalitas dan morbiditas yang tinggi. Tekanan darah tinggi pada pasien hipertensi dapat diatasi dengan terapi farmakologis dan non farmakologis. Salah satu terapi non farmakologis adalah terapi pijat wajah dan relaksasi napas dalam. Penelitian ini merupakan penelitian kuantitatif dengan metode Non- equivalent Control Group Design dengan pendekatan Control

Group Post test only design atau post tes kelompok control.
\end{abstract}

How to cite:

E-ISSN:

Published by:
Hasnani, Fenti (2021) Pengaruh Relaksasi Nafas Dalam dan Pijat Wajah Terhadap Tekanan Darah dan Stres Pada Ibu Hamil. Jurnal Health Sains 2(6). https://doi.org/10.46799/jhs.v2i6.190 2723-6927

Ridwan Institute 
Kata Kunci:

relaksasi nafas dalam; pijat wajah; perubahan tekanan

darah; tingkat stress; ibu hamil

\begin{abstract}
Penelitian dilakukan di Puskesmas Kelurahan Tanah Baru Depok. Sampel berjumlah 108 orang yang dibagi menjadi 54 orang pada kelompok kotrol dan 54 orang pada kelompok intervensi. Data dikumpulkan melalui kuisioner dan hasil pengukuran tekanan darah. Berdasarkan hasil uji Mann Whitney diperoleh hasil p-value 0,001, maka dapat disimpulkan adanya perbedaan rerata tekanan darah sistolik pada ibu hamil yang melakukan pijat wajah dan relaksasi napas dalam. Ada perbedaan yang signifikan nilai tingkat stres setelah melakukan pijat wajah dan relaksasi napas dalam pada tingkat stress (p-value 0,001). Rata-rata tingkat stress pada ibu hamil yang tidak melakukan terapi pijat wajahdan relaksasi nafas dalam adalah 76,50 $\pm 25,5$, sedangkan untuk ibu hamil yang melakukan terapi pijat wajah dan relaksasi nafas dalam adalah $60 \pm 16$.
\end{abstract}

\section{Pendahuluan}

Hipertensi dijuluki sebagai the silent killer karena biasanya tidak menunjukkan gejala dan hanya terdiagnosis melalui skrinning atau ketika hipertensi tersebut bermanifestasi pada komplikasi gangguan tertentu. Sistem kardiovaskuler selama kehamilan harus memenuhi kebutuhan yang meningkat antara ibu dan janin. Peningkatan curah jantung selama kehamilan berkisar 40\% pada trimester pertama dan kedua (Murray et al., 2004). Peningkatan curah jantung memungkinkan darah mengalir malalui sirkulasi tambahan yang terbentuk di uterus yang membesar dan dinding plasenta dan memenuhi kebutuhan tambahan pada organ lainnya di tubuh ibu hamil.

Pada kasus kehamilan dengan hipertensi, sindrom preeklamsia, baik terisolasi maupun bertumpang tindih dengan hipertensi kronis, merupakan yang paling berbahaya (William et al., 2013). Hipertensi dalam kehamilan adalah hipertensi yang ditemukan pada ibu hamil baik pada penyakit sebelumnya (5-15\% dari total ibu hamil) atau sebagai gangguan yang berhubungan dengan kehamilan, pre-eklamsia (Wylie \& Tregellas, 2010).

Dampak bagi ibu hamil dengan hipertensi beresiko lebih besar mengalami solusio plasenta, preeklamsia, dan rawat inap
(William et al., 2013). Sedangkan, dampak bagi janin adalah hambatan pertumbuhan janin. Penyakit hipertensi adalah komplikasi paling umum dari kehamilan yangmempengaruhi 6-8\% kehamilan di USA (Leeman et al., 2008). Di United Kingdom (UK), preeklampsia/eklampsia terhitung sebanyak 10-15\% dari kematian obstetric langsung (Akbar et al., 2012).

Di Indonesia angka kejadian preeklampsia cukup tinggi, seperti di Rumah Sakit Cipto Mangunkusumo ditemukan 400500 kasus/4000-5000 persalinan per tahun (Dharma et al., 2015). Hipertensi dalam kehamilan merupakan $5-15 \%$ penyulit kehamilan dan merupakan salah satu dari tiga penyebab tertinggi mortalitas dan morbiditashipertensi dalam kehamilan juga masih cukup tinggi (Sarwono \& Meinarno, 2009).

Penyebab hipertensi dalam kehamilan hingga kini belum diketahui dengan jelas. Banyak teori telah dikemukakan tentang terjadinya hipertensi dalam kehamilan, tetapi tidak ada satupun teori yang dianggap mutlak benar. Teori-teori sekarang banyak dianut adalah teori kelainan vaskularisasi plasenta, teori iskemi plasenta radikal bebas dan disfungsi endotel, teori intoleransi imunologik antara ibu dan janin, teori adaptasi kardiovaskularori genetic, teori defisiensi 
gizi, teori inflamasi (Sarwono \& Meinarno, 2009).

Hipertensi sangat signifikan berkontribusi terhadap angka kesakitan dan kematian ibu dan janin sehingga perlu dilakukan skrinning awal dan pemeriksaan lanjutan selama kehamilan. Hipertensi merupakan salah satu penyakit pada sistem kardiovaskuler yang memiliki angkamortalitas dan morbiditas yang tinggi. Tekanan darah tinggi pada pasien hipertensi dapat diatasi dengan terapi farmakologis dan non farmakologis. Salah satu terapi non farmakologis adalah terapi pijat wajah dan relaksasi napas dalam.

Fenomena hipertensi di Indonesia sebesar $9,5 \%$, yang terdiagnosis tenaga kesehatan atau sedang minum obat sebesar 9,4 \% (Trihono et al., 2013) menunjukan bahwa pasien hipertensi masih banyakmenggunakan pengobatan dengan cara terapi farmakologi. Selain terapi farmakologi, terapi nonfarmakologi bisa menurunkan tekanan darah tinggipasien hipertensi. Salah satuterapi nonfarmakologi yang dapat menurunkan tekanan darah adalah terapi relaksasi nafas dalam. Relaksasi napas dalam adalah pernafasan pada abdomen dengan frekuensi lambat serta perlahan, berirama, dan nyaman dengan cara memejamkan mata saat menarik nafas. Efek dari terapi ini ialahdistraksi atau pengalihan perhatian (Setyoadi et al., 2018).

Relaksasi nafas dalam merupakan suatu bentuk asuhan keperawatan, yang dalam hal ini mengajarkan kepada klien bagaimana cara melakukan nafas dalam, nafas lambat dan bagaimana menghembuskan nafas secara perlahan, selain itu dapat menurunkan intensitas nyeri, dapat meningkatkan ventilasi paru dan meningkatkan oksigenasi darah (Niken Syahfitri et al., 2010).

Terapi relaksasi nafas dalam mengubah frekuensi pernafasan menjadi 6 kali permenit dapat meningkatkan aktifitas baroreseptor sebagai prosesnya memberi impuls aferen mencapai pusat jantung, selanjutnya meningkatkan aktifitas sistem saraf parasimpatis dan melepaskan hormone asetilkolin yang meningkatkan permebilitas ionkalium di SA node sehingga menurunkan denyutan di SA node, penurunan transmisi impuls akan menurunkan denyut jantung, volume sekuncup dan curah jantung (Heru et al., 2013).

Latihan olah napas dan bermeditasi, seperti yoga atau taichi efektif untuk menurunkan hormone stress. Terapi relaksasi nafas dalam dapat meningkatkan saturasi oksigen, memperbaiki keadaan oksigenasi dalam darah, dan membuat suatu keadaan rileksdalam tubuh (Heru et al., 2013).

Teknik relaksasi nafas dalam merupakan suatu bentuk asuhan keperawatan, yang dalam hal ini perawat mengajarkan kepada klien bagaimana cara melakukan nafas dalam, nafas lambat (menahan inspirasi secara maksimal) dan bagaimana menghembuskan nafas secara perlahan. Selain dapat menurunkan intensitas nyeri, teknik relaksasi nafas dalam juga dapat meningkatkan ventilasi paru dan meningkatkan oksigenisasi darah (Smeltzer \&Bare, 2002).

Pijat atau massage didefinisikansebagai tindakan penekanan oleh tangan pada jaringan lunak, biasanya otot tendon atau ligamen tanpa menyebabkan pergeseran atau perubahan posisi sendi guna menurunkan nyeri, menghasilkan relaksasi, dan atau meningkatkan sirkulasi (Yunita, 2010). Sebagai cara kuno yang bebas efek samping pijat tidak hanya berkhasiat untuk menghilangkan lelah dan stress, tetapi juga dapat dipergunakan untuk menghilangkan stress dan meningkatkan kebugaran tubuh.

Kehamilan merupakan suatu kondisi perubahan fisik, psikis dan sosial. Seorang wanita dewasa yang sedang mengalami kehamilan dituntut harus siap secara fisik, tetapi juga harus siap secara mental (Psikologis). Hal inilah yang perlu diperhatikan ibu hamil yang umumnya terjadi 
pada setiap kehamilan, seperti perubahan bentuk tubuh dengan badan yang semakin membesar. Perubahan tersebut dapat mempengaruhi mental (Psikologis) ibu hamil sehingga perubahan ini pula yang dapatdengan mudah mempengaruhi stabilitas emosi ibu yang dapat berujung pada stres (Musbikin, 2006).

Penelitian yang dilakukan oleh (Rahmatika, 2014) tentang, Hubungan Antara Emotion-Focused Coping dan Stres Kehamilan, dengan hipotesis penelitian yang menyatakan bahwa ada hubungan negatif antara emotion-focused coping dan stres kehamilan pada ibu hamil diterima. Hal ini menunjukkan semakin tinggi tingkat emotionfocused coping yang digunakan oleh para wanita hamil maka semain rendah stres yang dialami, begitu pula sebaliknya.

Hasil penelitian (Harrison et al., 2007) mengatakan ibu hamil yang mengalami stres yang tinggi sehingga mengakibatkaninsomnia dapat meningkatkan tekanan darah ibu, dapat meningkatkan resiko kehamilan bayi prematur bahkan keguguran. Ibu yangmengalami stress mungkin mengalami tekanan yang sangat berat saat melahiran, fakor lainnya yaitu karena proses persalinan yang membuat trauma, kurangnya dukungan pada saat kehamilan dan persalinan, perasaan belum siap menjadi ibu misalnya karena usia terlalu muda.

Tujuan penelitian untuk Mengetahui Pengaruh Relaksasi Nafas Dalam dan Pijat WajahTerhadap Perubahan Tekanan Darah Dan Tingkat Stress Pada Ibu Hamil di Puskesmas Kelurahan Tanah Baru Depok.

Manfaat dari hasil penelitian ini diharapkan dapat memberikan manfaat baik manfaat teoretis maupun praktis.

\section{Metode Penelitian}

Desain penelitian yang digunakan adalah Non-equivalent Control Group Design, hanya pada desain ini kelompok kontrol tidak dipilih secara random.
Nonequivalent Control Group Design yaitu desain yang hampir sama dengan pre test-post test control group design, hanya pada desain ini kelompok eksperimen maupun kelompok kontrol tidak dipilih secara random (Sugiyono \& Kuantitatif, 2012).

Populasi dalam penelitian ini adalah seluruh ibu hamil dengan hipertensi yang melakukan kunjungan/pemeriksaan hamil di Puskesmas Tanah Baru Depok.

Penelitian ini menggunakan tehnik sampling jenuh yaitu tehnik penentuan sampel bila semua anggota populasidigunakan sebagai sampel (Hidayat et al., 2014). Sampel yang digunakan adalah ibu hamil dengan hipertensi yang melakukankunjungan/pemeriksaan hamil di Puskesmas Tanah Baru Depok. Sampel yang akan digunakan pada penelitian ini adalah sampel yang memenuhi Kriteria inklusi dan eksklusi.

Penelitian ini akan dilaksanakan di Puskesmas Kelurahan Tanah Baru Depok. Waktu penelitian April - Oktober 2018.

\section{Hasil dan Pembahasan}

A. Analisis Multivariat

Tujuan dari analisa ini adalah untuk menjelaskan atau mendeskripsikan karakteristik masing-masing variabel yang diteliti. Analisa ini dilakukan terhadap tiap variabel penelitian. Dalam penelitian iniada beberapa variabel yang akan dianalisis antara lain variabel usia, pendidikan tertinggi, kerja, gravida, partus, abortus, usia kehamilan, tekanan darah, dan tingkat stress pada ibu hamil.

\section{Tabel 1}

Distribusi Frekuensi Karakteristik Ibu Hamil di Puskesmas Kelurahan Tanah Baru Depok Tahun 2018

\begin{tabular}{clcc}
\hline \multicolumn{2}{c}{ Karakteristik } & $\begin{array}{r}\text { Kelompok } \\
\text { Intervensi }\end{array}$ & $\begin{array}{c}\text { Kelompok } \\
\text { Kontrol }\end{array}$ \\
\hline Umur & $>$ & $85(14.8 \%)$ & $46(85.2 \%)$ \\
& tahun & & \\
\hline & $\begin{array}{l}20-35 \\
\text { tahun }\end{array}$ & $7(13 \%)$ & $47(87 \%)$ \\
\hline Pendidikan & SMTP & 0 & 0 \\
\hline
\end{tabular}




\begin{tabular}{|c|c|c|c|}
\hline & SMTA & $24(44.4 \%)$ & $30(55.6 \%)$ \\
\hline & Sarjana & $30(55.6 \%)$ & $24(44.4 \%)$ \\
\hline \multirow[t]{3}{*}{ Pekerjaan } & Bekerja & $32(59.3 \%)$ & $13(24.1 \%)$ \\
\hline & Tidak & $22(40.7 \%)$ & $41(75.9 \%)$ \\
\hline & Bekerja & & \\
\hline \multirow[t]{2}{*}{ Gravida } & $>5 \mathrm{kali}$ & $5(9.3 \%)$ & $4(7.4 \%)$ \\
\hline & $<5$ kali & $49(90.7 \%)$ & $50(92.6 \%)$ \\
\hline \multirow[t]{2}{*}{ Partus } & $>4$ kali & $5(9.3 \%)$ & $5(9.3 \%)$ \\
\hline & $<4$ kali & 49 (90.7) & $49(90.7 \%)$ \\
\hline \multirow[t]{2}{*}{ Abortus } & Ada & $22(40.7 \%)$ & $22(40.7 \%)$ \\
\hline & Tidak & $32(59.3 \%)$ & $32(59.3 \%)$ \\
\hline Usia & $>28$ minggu & $30(55.6 \%)$ & $29(53.7 \%)$ \\
\hline \multicolumn{4}{|l|}{ Kehamilan } \\
\hline & $\begin{array}{l}20-27 \\
\text { minggu }\end{array}$ & $.45)$ & B\%) \\
\hline
\end{tabular}

Hasil analisis data pada tabel 1 menunjukkan bahwa karakteristik dari 108 responden di Puskesmas Kelurahan Tanah Baru Depok tahun 2018 diperoleh pada kelompok intervensi dengan jumlah 54 responden sebagian besar ibu hamil berusia 20-35 tahun sebanyak 46 orang $(85,2 \%)$ dan sisanya sebanyak 8 orang $(14,8 \%)$ berusia $>35$ tahun. Padakelompok kontrol dengan jumlah 54 responden didapatkan sebagian besar ibu hamil berusia 20-35 tahun sebanyak 47 orang $(87 \%)$ dan sisanya sebanyak 7 orang $(13 \%)$ berusia $>35$ tahun.

Hasil penelitian ini sejalan dengan penelitian yang dilakukan oleh (Setiadhi et al., 2016) yang berjudul analisis faktor yang berhubungan dengan kejadian hipertensi pada kehamilan di Kota Manado didapatkan sebagian besar usia ibu hamil pada rentang umur 20-25 tahun memiliki jumlah paling tinggi sebanyak 62 responden (43\%), dan yang paling rendah adalah yang berumur diatas 40 tahun sebanyak 4 responden (2.8\%).

Hasil penelitian ini sejalan dengan penelitian yang dilakukan oleh (Fahrudin, 2018) yang berjudul faktor yang berhubungan dengan kejadian hipertensi pada ibu hamil di wilayah kerja Puskesmas Suli Kabupaten Luwudidapatkan sebagian besar usia ibu hamil pada kelompok umur 20-35 tahun< yakni sebanyak 33 Orang $(45,3 \%)$ dan terendah pada kelompok umur $<20$ tahun sebanyak 11 orang $(15,0 \%)$.

Hasil penelitian ini sejalan dengan penelitian yang dilakukan oleh (Indriani, 2014) yang berjudul Analisis FaktorFaktor yang Berhubungan dengan Preeklampsia pada Ibu Bersalin Di Rsu Daerah Kardinah Kota Tegal Tahun 2011 sebagian besar responden berusia 20-35 tahun $(85 \%)$, sedangkan umur $>35$ tahun proporsinya $15 \%$.

Hipertensi (preeklampsia-eklamsi) meningkat di umur muda, sehubungan dengan belum sempurnanya organ-organ yang ada ditubuh wanita untuk bereproduksi, selain itu faktor psikologis yang cenderung kurang stabil juga meningkatkan kejadian preeklampsiadi umur muda. Hal ini juga sesuai denganstudi di RS Neutra Colombia, Porapakkan di Bangkok, dan lainnya di Zambia, cenderung terlihat insiden hipertensi (preeklamsia-eklamsi) cukup tinggi di usia belasan tahun (Indriani, 2014).

Umur merupakan bagian dari status reproduksi yang penting. Umur berkaitan dengan peningkatan atau penurunan fungsi tubuh sehingga mempengaruhi status kesehatan seseorang. Salah satu penelitian menyatakan bahwa wanita usia remaja yang hamil untuk pertama kali dan wanita yang hamil pada usia 30 - 35 tahun mempunyai resiko yang sangat tinggi untuk mengalami preeklampsia. Pada usia 30 - 35 tahun atau lebih akan terjadi perubahan pada jaringan dan alat reproduksi serta jalan lahir tidak lentur lagi. Pada usia tersebut cenderung didapatkan penyakit lain dalam tubuh ibu, salah satunya hipertensi. Usia ibu yang terlalu tua saat hamil mengakibatkan gangguan fungsi organ karena proses degenerasi. Proses degenerasi organ reproduksi akan berdampak langsung padakondisi ibu saat menjalani proses kehamilan dan persalinan yang salah 
satunya adalah preeklampsia (Giovanna et al., 2017).

Menurut (Norwitz \& Lye, 2008) yang menyatakan bahwa umur merupakan salah satu faktor risiko terjadinya hipertensi dalam kehamilan. Kehamilan pada umur ibu yang ekstrem $(<20$ dan $>35$ tahun) merupakan kehamilan berisiko tinggi yang dapat menyebabkan komplikasi dalam kehamilan komplikasi utama kehamilan dibawah umur $<20$ dan

$>35$ tahun ini yakni terjadinya preeklampsia. Ibu mengalami hipertensi disertai kaki bengkak dan ditemukan protein pada air seni (Kurniawati et al., 2015).

Usia yang aman untuk kehamilan dan persalinan adalah 20-35 tahun. Komplikasi maternal pada wanita hamil dan melahirkan pada usia dibawah 20 tahun ternyata 2-5 kali lebih tinggi dari pada kematian maternal yang terjadi pada usia 20-29 tahun. Dampak dari usia yang kurang, dapat menimbulkan komplikasi

selama kehamilan. Setiap remaja primigravida mempunyai risiko yang lebih besar mengalami hipertensi dalam kehamilan dan meningkat lagi saat usia diatas 35 tahun (Manuaba, 2008).

Berdasarkan pendidikan ibu hamil menjelaskan bahwa dari 108 responden di Puskesmas Kelurahan Tanah Baru Depok tahun 2018, pada kelompok intervensi didapatkan sebagian besar responden berpendidikan sarjana sebanyak 30 orang $(55,6 \%)$ dan sisanya 24 orang $(44,4 \%)$ berpendidikan SMTA, sedangkan pada kelompok kontrol sebagian besar responden berpendidikan Sarjana dan SMTA sebanyak 25 orang $(46,3 \%)$ dan sisanya 4 orang $(7,4 \%)$ berpendidikan SMTP.

Hasil penelitian ini sejalan dengan penelitian yang dilakukan oleh (Setiadhi et al., 2016) yang berjudul analisis faktor yang berhubungan dengan kejadian hipertensi pada kehamilan di Kota Manado didapatkan sebagian besar pendidikan ibu hamil pada jenjang pendidikan tamat SMA sebanyak 91 responden $(63.2 \%)$ sedangkan yang paling sedikit adalah tamat SD sebanyak 5 responden $(3.5 \%)$

B. Analisis Bivariat

Analisa bivariat digunakan untuk menganalisis efektivitas antara variabel independen adalah intervensi dan kontrol dengan variabel dependen adalah tingkat Stress. Kedua variabel tersebut diuji menggunakan Uji t-Dependen dan Independent yang sebelumnya dilakukanuji normalitas dengan menggunakan metode Shapiro Wilk dimana bila p-value $<0,05$ yang berarti data tidak berdistribusi normal. Hasil statistik komputerisasi dapat dilihat pada tabel 2 berikut ini:

\section{Tabel 2}

\section{Uji Normalitas Tekanan Darah Sistolik} dan Diastolik

\begin{tabular}{|c|c|c|c|c|c|c|c|}
\hline \multicolumn{8}{|c|}{ Test Of Normality } \\
\hline & \multirow[t]{2}{*}{ njknkkmTerapi } & \multicolumn{3}{|c|}{$\begin{array}{c}\text { Kolmogorov }^{-} \\
\text {sminov }\end{array}$} & \multicolumn{3}{|c|}{ Shapiro-Wilk } \\
\hline & & $\underline{\text { Stati: }}$ & $\underline{\mathrm{df}}$ & Sig. & $\underline{\text { Statisti }}$ & $\mathrm{df}$ & $\underline{\mathrm{Si}}$ \\
\hline TDS & Kontrol & .144 & 54 & 007 & 917 & 54 & .0( \\
\hline PIe & Eksperimen & .085 & $\underline{54}$ & 200 & .980 & 54 & .45 \\
\hline TDS & Kontrol & .117 & 54 & 061 & .945 & 54 & .01 \\
\hline Pos & Eksperimen & .136 & $\underline{54}$ & 014 & .951 & 54 & .04 \\
\hline TDS & Kontrol & .091 & 54 & $=200$ & .957 & 54 & .04 \\
\hline Pos & Eksperimen & .118 & 54 & 058 & .929 & 54 & .00 \\
\hline TDS & Kontrol & .207 & 54 & .000 & .930 & 54 & .00 \\
\hline Pos & Eksperimen & .182 & $\underline{54}$ & 000 & .957 & 54 & 0 \\
\hline
\end{tabular}

Pada tabel 2 data variable tekanan darah sistolik dan diastolik pre dan post yang bersistribusi normal hanya variabel TDS pre Eksperimen dan TDD pos eksperimen, sisanya tidak normal. Dengan demikian antara variable tekanan darah sistolik dan diastolic pre serta post dilakukan uji Wilcoxon dan Mann Whitney. Untuk variable tingkat stress menggunakan uji Dependen dan Independen. 
Tabel 3

Uji Normalitas Tingkat Stress Pre dan

\begin{tabular}{|c|c|c|c|c|}
\hline \multicolumn{5}{|c|}{ Post } \\
\hline Variabel & Skewnes & $\begin{array}{l}\text { SE } \\
\text { Skewness }\end{array}$ & $\begin{array}{l}\text { Rasio } \\
\text { Skewness }\end{array}$ & Hasil \\
\hline Stres Pre &,- 445 &, 233 & 1,9 & $\underline{\text { Normal }}$ \\
\hline Stres Post & 301 & 233 & 1,2 & Normal \\
\hline
\end{tabular}

Pada tabel 3 data variable stress pre dan post bersistribusi normal dengan rasio skewnes antara -2 s.d +2 , sehingga diperoleh hasil variable sistolik pre dan variable diastolic pre tidak untuk variable tingkat stress menggunakan uji Dependen dan Independen.

C. Analisis Multivariat

Pada kelompok intervensi diperoleh rata-rata tingkat stress pre ibu hamil adalah $75,6 \pm 21,1$, sedangkan untuk rata- rata tingkat stress post ibu hamil adalah 60

\pm 16 . Terlihat nilai mean perbedaan antara pengukuran tingkat stress pre dan post adalah 15,6. Hasil uji statistic didapatkan nilai 0,001 maka dapat disimpulkan ada perbedaan yang signifikan antara tingkat stress pre dan post.

Pada kelompok kontrol diperoleh rata-rata tingkat stress pre ibu hamil adalah $68,5 \pm 22$, sedangkan untuk rata- rata tingkat stress post ibu hamil adalah 76,5 \pm 25,5 . Terlihat nilai mean perbedaan antara pengukuran tingkat stress pre dan post adalah 8. Hasil uji statistic didapatkan nilai 0,001 maka dapat disimpulkan ada perbedaan yang signifikan antara tingkat stress pre dan post.

\section{Tabel 4}

Perbedaan Rata-Rata Tingkat Stress

Pada Ibu Hamil Kelompok Intervensi dan Kelompok Kontrol di Puskesmas Kelurahan Tanah Baru Depok Tahun 2018

\begin{tabular}{|c|c|c|c|c|c|}
\hline Kelompok & Variabel & Mea SD & $\underline{\text { SE }}$ & P-Value & $\mathbf{N}$ \\
\hline \multirow[t]{2}{*}{ Intervensi } & Stres Pre & $\overline{75,6} \quad \overline{21,1}$ & 2,8 & 0,001 & 54 \\
\hline & $\begin{array}{c}\text { Stres } \\
\text { Post }\end{array}$ & 16 & 2,1 & & \\
\hline \multirow[t]{2}{*}{ Control } & Stres Pre & $68,5 \quad 22$ & 3 & 0,001 & 54 \\
\hline & $\begin{array}{c}\text { Stres } \\
\text { Post }\end{array}$ & $76,5 \quad 25,5$ & 3,4 & & \\
\hline
\end{tabular}

Dari hasil interpretasi diatas, pada kelompok intervensi antara tingkat stress pre dengan post diperoleh selisih rata-rata yang berkurang sebanyak 15,6 , sedangkan pada kelompok kontrol diperoleh selisih rata-rata bertambah 8 . Kesimpulannya adalah pada ibu hamil yang melakukan terapi pijat wajah dan relaksasi dapat menurunkan tingkat stress dibanding pada kelompok kontrol yang tidak diberikan intervensi.

Hasil penelitian (Ayumi et al., 2014) ini didapatkan bahwa sebagian besar responden sebelum dilakukan relaksasi nafas dalam mengalami hipertensi stadium 1 yaitu sebanyak 16 reponden $(53,4 \%)$ dan setelah dilakukan relaksasi nafas dalam didapatkan bahwa sebagian besar responden mengalami tekanan darah normal yaitu sebanyak 13 responden $(43,4 \%)$. Hasil uji wilcoxon sign test dengan tingkat kemaknaan a $=0,05$ didapatkan nilai asymp sig (2-tailed) < 0,05 yaitu $0,002<0,05$ maka artinya ada pengaruh relaksasi nafas dalam terhadap penurunan tekanan darah pada ibu hamil hipertensi di Puskesmas KenditKecamatan Kendit Situbondo.

Stres pada perempuan memiliki keterkaitan dalam menimbulkan stres saat mengandung dan melahirkan dan hal ini berdasarkan hasil penelitian dari Leifer tentang kondisi stres pada masa kehamilan dan persalinan serta penelitian Radley tentang stres dalam kehidupan. Adapun stres atau kecemasan para ibu hamil lainnya, berkaitan dengan keselamatan dan kesehatan bayi yang akan dilahirkannya dan persiapan biaya yang dibutuhkan saat persalinan dan perawatan bayi yang akan dilahirkan. Ketakutan pada ibu hamil meliputi ketakutan akankematian setelah melahirkan. 


\section{Kesimpulan}

Bagian ini akan membahas secara sistematis kesimpulan dan saran dari penelitian yang berjudul Pengaruh Relaksasi Nafas Dalam dan Pijat Wajah Terhadap Perubahan Tekanan Darah Dan Tingkat Stress Pada Ibu Hamil di Puskesmas Kelurahan Tanah Baru Depok. Kesimpulan yang diperoleh merupakan analisa hasil penelitian yang telah dilakukan dengan menggunakan metodologi ilmiah.

Gambaran karakteristik dari pada kelompok intervensi (terapi pijat dan relaksasi nafas dalam) dari 54 responden yang diteliti terlihat bahwa sebagian besar ibu hamilberusia 20-35 tahun sebanyak 46 orang $(85,2 \%)$, berpendidikan sarjana sebanyak 30 orang $(55,6 \%)$, yang bekerja sebanynak 32 orang $(59,3 \%)$, gravida (jumlah kehamilan) < 5 kali sebanyak 49 orang $(90,7 \%)$, jumlah persalinan $<4$ kali sebanyak 49 orang $(90,7 \%)$, tidak pernah abortus sebanyak 32 orang $(59,3 \%)$, usia kehamilan $>28$ minggu sebanyak 30 orang $(55,6 \%)$, rata-rata tekanan darah sistolik pre adalah $135 \mathrm{mmHg} \pm 4,9$ $\mathrm{mmHg}$, rata-rata tekanan darah sistolik post adalah $116,3 \mathrm{mmHg} \pm 9,9 \mathrm{mmHg}$, rata-rata tekanan darah diastolik pre $92,8 \mathrm{mmHg} \pm 5,6$ $\mathrm{mmHg}$ rata-rata tekanan darah diastolik post $84,7 \mathrm{mmHg} \pm 5,2 \mathrm{mmHg}$, rata-rata tingkat stress pre adalah 75,6 $\pm 21,1$, rata-rata tingkat stress post adalah $60 \pm 16$.

Gambaran karakteristik dari pada kelompok kontrol (tidak melakukan terapi) dari 54 responden yang diteliti terlihat bahwa sebagian besar ibu hamil berusia 20-35 tahun sebanyak 47 orang $(87 \%)$, berpendidikan Sarjana dan SMTA sebanyak 25 orang $(46,3 \%)$, yang tidak bekerja sebanyak 41 orang (75,9\%), gravida (jumlah kehamilan) <

5 kali sebanyak 50 orang $(92,6 \%)$, jumlah persalinan < 4 kali sebanyak 49 orang $(90,7 \%)$, tidak pernah abortus sebanyak 32 orang $(59,3 \%)$, usia kehamilan $>28$ minggu sebanyak 29 orang $(53,7 \%)$, rata-rata tekanan darah sistolik pre adalah 130,6 $\mathrm{mmHg} \pm 6,4$
$\mathrm{mmHg}$, rata-rata tekanan darah sistolik post adalah $117,9 \mathrm{mmHg} \pm 10,3 \mathrm{mmHg}$, rata-rata tekanan darah diastolik pre $89,6 \mathrm{mmHg} \pm 7,1$ $\mathrm{mmHg}$, rata-rata tekanan darah diastolik post $84,8 \mathrm{mmHg} \pm 7,1 \mathrm{mmHg}$, rata-rata tingkat stress pre adalah $68,5 \pm 2$, rata-rata tingkat stress post adalah $76,5 \pm 25,5$.

Ada perbedaan yang signifikan nilai tekanan darah setelah melakukan pijat wajah dan relaksasi napas dalam pada tekanan darah sistolik (p-value 0,001) dan diastolik ( $p$-value 0,026). Dari analisa diatas, diperoleh hasil bahwa pada ibu hamil yang melakukan terapi pijat wajah dan relaksasi nafas dalam didapatkan lebih cenderung menurunkan tekanan darah sistolik $(-27,5 \mathrm{mmHg})$ dan diastolic $(-27,1 \mathrm{mmHg})$, dibandingkan dengan ibu hamil yang tidak melakukan terapi pijat wajah dan relaksasi napas dalam msaih didapatkan peningkatan tekanan darah sistolik $(+12,75 \mathrm{mmHg})$ dan diastolic $(+15,92 \mathrm{mmHg})$. Berdasarkan hasil uji Mann Whitneydiperoleh hasil p-value 0,001, maka dapat disimpulkan adanya perbedaan rerata tekanan darah sistolik pada ibu hamil yang melakukanpijat wajah dan relaksasi napas dalam.

Ada perbedaan yang signifikan nilai tingkat stres setelah melakukan pijat wajahdan relaksasi napas dalam pada tingkat stress (pvalue 0,001 ). Rata-rata tingkat stress pada ibu hamil yang tidak melakukan terapi pijat wajah dan relaksasi nafas dalam adalah 76,50

$\pm 25,5$, sedangkan untuk ibu hamil yang melakukan terapi pijat wajah dan relaksasi nafas dalam adalah $60 \pm 16$.

\section{BIBLIOGRAFI}

Akbar, M. A., Ali, N. H., \& Zayed, E. M. E. (2012). A Generalized And ImprovedExpansion Method For Nonlinear Evolution Equations. Mathematical Problems In Engineering, 2012. Google Scholar

Ayumi, S., Yamazaki, O., Horita, S., Nakamura, M., Satoh, N., Yamada, H., 
Suzuki, M., Kudo, A., Kawakami, H., \& Hofmann, F. (2014). Angiotensin Ii Dose-Dependently Stimulates Human Renal Proximal Tubule Transport By The Nitric Oxide/Guanosine 3!, 5!- Cyclic Monophosphate Pathway. Google Scholar

Dharma, S., Kedev, S., Patel, T., Kiemeneij, F., \& Gilchrist, I. C. (2015). A Novel Approach To Reduce Radial Artery Occlusion After Transradial Catheterization: Postprocedural/Prehem ostasis Intra-Arterial Nitroglycerin. Catheterization And Cardiovascular Interventions, 85(5), 818-825. Google Scholar

Fahrudin, A. (2018). Development Of Physics Summary Book As A SmartphoneBased Application And Its Effect On Elasticity Learning Achievement. Kasuari: Physics Education Journal (Kpej), 1(1), 22-33. Google Scholar

Giovanna, B., Ortiz, O., \& Alacaniz, J. M. (2017). Can Biochar Protect Labile Organic Matter Against Mineralization In Soil? Pedosphere, 27(5), 822-831. Google Scholar

Harrison, G. W., Lau, M. I., \& Rutström, E. E. (2007). Estimating Risk Attitudes In Denmark: A Field Experiment. Scandinavian Journal of Economics, 109(2), 341-368. Google Scholar

Heru, P., Priadi, D., \& Lumingkewas, H. R. (2013). Strength Improvement Of Early Age Unfired Soil Lime Bricks. Advanced Materials Research, 689, 299303. Google Scholar

Hidayat, H., Hoitink, A. J. F., Sassi, M. G., \& Torfs, P. (2014). Prediction OfDischarge In A Tidal River Using Artificial Neural Networks. Journal of Hydrologic Engineering, 19(8),

4014006. Google Scholar
Indriani, S. (2014). Faktor Risiko Yang Berhubungan Dengan Kejadian Kusta (Studi Kasus Di Wilayah Kerja Puskesmas Kunduran Blora Tahun 2012). Universitas Negeri Semarang. Google Scholar

Kurniawati, E. P., Nugroho, P. I., \& Arifin, C. (2015). Penerapan Akuntansi PadaUsaha Mikro Kecil Dan Menengah (Umkm). Jurnal Manajemen Dan Keuangan, 10(2). Google Scholar

Leeman, M., Östman, E., \& Björck, I. (2008). Glycaemic And Satiating Properties Of Potato Products. European Journal Of Clinical Nutrition, 62(1), 87-95. Google Scholar

Manuaba, I. B. P. (2008). Understanding The Theory Of Social Construction. Ijjs, 21(3), 221-230. Google Scholar

Murray, E., Burns, J., Tai, S. S., Lai, R., \& Nazareth, I. (2004). Interactive Health Communication Applications For People With Chronic Disease. Cochrane Database Of Systematic Reviews, 4. Google Scholar

Musbikin, I. (2006). Rahasia Shalat: Bagi Penyembuhan Fisik Dan Psikis. Mitra Pustaka. Google Scholar

Niken Syahfitri, W. V., Kurniawati, S., Santoso, M., Adventini, N., Lestiani, D. D., \& Damastuti, E. (2010). Method Comparison Of Naa And Ssa On Determination Of $\mathrm{Fe}, \mathrm{Zn}$ And $\mathrm{Hg}$ In Spirulina Platensis; Komparasi Metode Analisis Aktivasi Neutron Dan Spektrometri Serapan Atom Pada Penentuan Unsur Fe, Zn, Dan Hg Dalam Spirulina Platensis. Google Scholar

Norwitz, E. R., \& Lye, A. J. (2008). Biology Of Parturition. Resnick's Maternal-Fetal Medicine. 6th Edition. Philadelphia: Saunders Elseiver, 6, 69-85. Google Scholar 
Rahmatika, R. (2014). Hubungan Antara Emotion-Focused Coping Dan Stres Kehamilan. Jurnal Psikogenesis, 3(1), 92-103. Google Scholar

Sarwono, S. W., \& Meinarno, E. A. (2009). Psikologi Sosial. Jakarta: Salemba Humanika, 77. Google Scholar

Setiadhi, Y., Kawengian, S. E. S., \& Mayulu, N. (2016). Analisis Faktor Yang Berhubungan Dengan Kejadian Hipertensi Pada Kehamilan Di Kota Manado. Ebiomedik, 4(2). Google Scholar

Setyoadi, S., Kristianto, H., \& Afifah, S. N. (2018). Influence Of Nutrition Education With Calendar Method In Diabetic Patients' Blood Glucose. Nurseline Journal, 3(2), 72-80. Google Scholar

Smeltzer, S. C., \& Bare, B. G. (2002). Buku Ajar Keperawatan Medikal Bedah. Jakarta: Egc, 1223, 21. Google Scholar

Sugiyono, M. P. P., \& Kuantitatif, P. (2012). Kualitatif, Dan R\&D, Bandung: Alfabeta. Cet. Vii. Google Scholar
Trihono, P. P., Windiastuti, E., Pardede, S. O., Endyarni, B., \& Alatas, F. S. (2013). Pelayanan Kesehatan Anak Terpadu. Departemen Ilmu Kesehatan Anak FkuiRscm. Google Scholar

William, B. M., Bongu, N. R., Bast, M., Bociek, R. G., Bierman, P. J., Vose, J. M., \& Armitage, J. O. (2013). The Utility Of Lactate Dehydrogenase In The Follow Up Of Patients With Diffuse Large B-Cell Lymphoma. Revista Brasileira De Hematologia E Hemoterapia, 35(3), 189-191. Google Scholar

Wylie, K. P., \& Tregellas, J. R. (2010). The Role Of The Insula In Schizophrenia. Schizophrenia Research, 123(2-3), 93104. Google Scholar

Yunita, F. A. (2010). Studi Komparasi Metode Pembelajaran Simulasi Dengan Demonstrasi Terhadap Pencapaian Kompetensi Dalam Pertolongan Persalinan Kala Iii Di Akademi Kebidanan Kusuma Husada Surakarta. Uns (Sebelas Maret University). Google Scholar

\section{Copyright holder:}

Fenti Hasnani (2021)

First publication right:

Jurnal Health Sains

This article is licensed under:

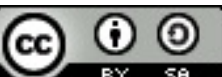

